\title{
Charles Richard Drew (1904-1950): Father of blood banking
}

\author{
Siang Yong $\underline{\operatorname{Tan}}^{1}$, MD, Christopher $\underline{\text { Merritt }}^{2}$, MD
}

E very two seconds, a blood transfusion is required in the United States. An eminent pioneer in the field was Charles Richard Drew, whose work on the banking of blood products and the logistics of collecting and distributing blood saved countless lives in the trenches of World War II and the wards of military and civilian hospitals. Equally important to his legacy was Drew's dedication to racial equality in segregated America, which served to inspire a nation that was striving toward justice for all.

NO SILVER SPOON Drew, an African American, was the first child born to a poor family on 3 June 1904 in Washington, DC, USA. As a young boy, he contributed to his family's income by delivering newspapers in the neighbourhood. He showed an early ability to coordinate and manage, organising his paper route with those of ten childhood friends into a network that delivered 2,000 newspapers daily.

At the age of 14 , Drew matriculated at Paul Laurence Dunbar High School, Washington, DC. Educational opportunities for African Americans were limited in the early 20th century, but Dunbar High School was an exception and a beacon of hope for many black families. Its reputation was stellar, and its teachers earned the same salary as the city's white teachers. African American families from around the nation moved to Washington so that their children could attend the school and benefit from this excellent environment.

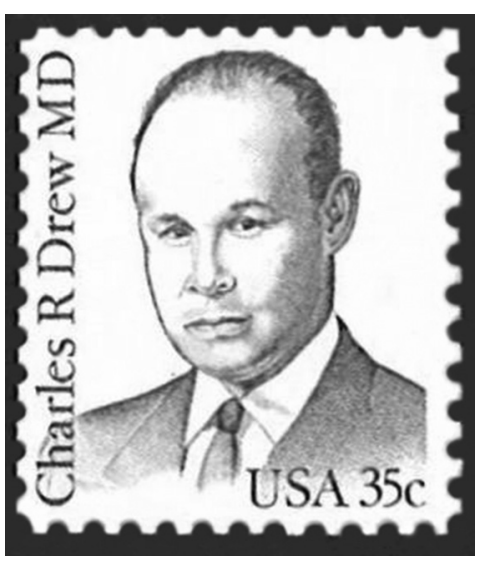

meagrely in order to repay his undergraduate debt and save money for medical school. Drew was eligible to apply to only two US schools. One was Howard University with its associated Freedmen's Hospital, which was created to serve freed slaves during the American Civil War, and the other was Harvard Medical School. Howard did not accept Drew because he lacked the required number of humanities course credits. Harvard said yes, but placed him on the waiting list for the following year. Impatient to begin his medical studies, Drew declined the Harvard offer and instead applied to McGill University in Montreal, Canada. Upon his acceptance, Drew packed his belongings and set out for Canada in 1928.

In 1933, McGill conferred upon Drew the degrees of Doctor of Medicine and Master of Surgery. Over the following two years, he completed an internship in pathology and a resident year in internal medicine at Montreal's the Royal Victoria Hospital and Montreal General Hospital, respectively. His father died in 1934, prompting Drew to accept a position as instructor of pathology at Howard University's medical school in order to be near his mother and four younger siblings. In 1936, he completed a one-year surgical residency at Freedmen's Hospital.

BURGEONING INTEREST IN BLOOD BANKING At that time, it was known that fatal reactions and lysis of red blood cells occurred when animal blood was transfused into humans. In 1901, Karl Landsteiner reported that these reactions can

COLLEGE AND MEDICAL SCHOOL Drew excelled in nearly every sport his high school offered, landing a partial athletic scholarship at Amherst College, Massachusetts, in 1922. At Amherst, he focused on track and football, receiving both the Howard Hill Mossman Trophy, for bringing the most honour in athletics to the school, and the Thomas W Ashley trophy, for being the most valuable football player. He graduated in 1926, one of only 16 African Americans to do so during the 1920s. As incredible as that achievement was, Drew had already set his sights on his next and even more ambitious educational goal-medical school.

Drew's scholarship from Amherst was generous but did not completely cover the significant costs of his college education. In the fall of 1926, he began work at Morgan State University in Baltimore, Maryland, and for the next two years, lived also occur when incompatible blood is transfused between humans. Landsteiner won the Nobel Prize for Physiology or Medicine in 1930 for his discovery of blood group antigens; that same year, Drew, then a medical student, began his research in transfusion medicine with Dr John Beattie, a visiting British professor at McGill. Drew and Dr Beattie's initial work centred on the process of degradation of blood under various conditions of storage and anticoagulation. Notwithstanding Landsteiner's discovery, the practicality of transfusing blood remained an impediment. There were no refined methods for the separation of blood components, so only whole blood, which has a shelf life of one week, could be used. Hospitals struggled to maintain a ready supply of blood for their patients, but due to its rapid expiration, blood of the appropriate type was frequently unavailable. 
In 1938, Drew was accepted as a Rockefeller Fellow at Columbia University's renowned Presbyterian Hospital, New York, to study the storage and distribution of blood. There, he further investigated the lifespan of stored blood under various conditions and, as manager of the hospital's blood supply, turned his attention to the separation of blood components. In 1939, he developed novel methods of separating plasma from erythrocytes and dramatically increased the shelf life of plasma to two months. Although plasma lacked the oxygen-carrying capacity of whole blood, it was an exceedingly useful product for the replacement of volume and clotting factors, especially in victims of trauma and war.

WAR ABROAD, OPPORTUNITY AT HOME Drew completed his dissertation, Banked Blood: A Study in Blood Preservation, and was awarded a Doctor of Science degree. At the time, there was no national blood bank, although a handful of local stations existed, such as the New York Blood Transfusion Betterment Association. In 1940, the office of the US Surgeon General and the National Research Council approached this association to organise a programme to ship plasma to Britain. Adolf Hitler's aerial force, the Luftwaffe, was heavily bombing England, and there was enormous demand for plasma for war victims. Furthermore, it was becoming increasingly apparent that the US was likely to enter the war, and the US government realised that establishing the skills and networks to ship plasma overseas could prove very valuable. Drew was tapped as the medical director of this project, which came to be known as the Blood for Britain campaign.

Drew excelled at the task, overseeing the collection and distribution to Britain of tens of thousands of units of plasma. Following the conclusion of the project the following year, the Red Cross enlisted him to start a pilot programme that included innovations such as community donation centres in storefronts, factories and 'bloodmobiles'. The blood was processed in a single central laboratory under strict, uniform standards. Drew's success led to his appointment as director of the organisation's New York blood bank, tasked with collecting blood from 100,000 donors for the American military.
MORAL IMPERATIVE Unfortunately, conflict over racial policy led to Drew's resignation from the Red Cross shortly after his appointment. At that time, America was still wholly segregated, and the military and the Red Cross adopted a policy of identifying the donor's race on every unit of blood collected so that white patients would not receive blood from black donors. Drew felt that the policy was ridiculous and insulting. He said, "It was a bad mistake for three reasons: (1) no official department of the Federal Government should wilfully humiliate its citizens; (2) there is no scientific basis for the order; (3) they need the blood." He left the Red Cross in 1942 and returned to Howard University as chief surgeon at Freedmen's Hospital.

Drew became a beloved and inspirational teacher even as he continued to research, publish and denounce the racist and unscientific policies of the government. In 1943, at only 39 years old, he became the first African American examiner for the American Board of Surgery and, in 1946, a Fellow of the International College of Surgeons.

Sadly, his life ended just four years later. True to his tireless devotion to medicine, he awoke early on 31 March 1950, performed surgery, lectured to his students and had dinner with his family. He then returned to the hospital after midnight to do his rounds before driving all night from Washington, DC, to attend a conference of African American physicians in Tuskegee, Alabama. Near Greensboro, North Carolina, Drew presumably fell asleep, and his car struck a tree. Critically injured, he was rushed to the nearby Alamance General Hospital, but could not be resuscitated. Rumours quickly spread that Drew had died because the white physicians there had denied him a blood transfusion, although these rumours turned out to be unfounded.

\section{BIBLIOGRAPHY}

- Bull DC, Drew CR. The Preservation of Blood. Ann Surg 1940; 112: 498-501.

- Hallman L, American Red Cross. Legacy and Memory of Charles Drew Lives On. Available at: http://archive.fo/ApbOl. Accessed August 3, 2017.

- Love S. One Blood: the Death and Resurrection of Charles R Drew. Chapel Hill: The University of North Carolina Press, 1996.

- Nobel Lectures, Physiology or Medicine 1922-1941. Amsterdam: Elsevier Publishing Company, 1965.

- Society for Black Academic Surgeons. Charles Drew: Black American Medical Pioneer. Available at: https://archive.li/K5twG. Accessed August 4, 2017. 